\title{
POVESTE DESPRE UN ARÂNG. MOTIVUL CÂNTECULUI LITURGIC LA ADAM PUSLOJIĆ
}

Ne propunem să analizăm motivul cântului liturgic în poezia lui Adam Puslojić. Corpusul literar: ultimul volum de poezii al poetului sârb, Cerul, în direct, publicat în 2019. Metodologie: Demers tematic.Tema muzicii, laolaltă cu motivul cântului, al arborelui vieții, al îngerului și al clopotului, definițiile poetice formează 'sinapse, legături și semne' (denumite ca atare într-una din subdiviziunile volumului) pe care le analizăm în cheie hermeneutică. Motivul instrumentului muzical se combină aici cu tema religioasă, a căutării vieții de Apoi. Ipoteza de lucru: poeziile acestui volum formează strofe din 'cântecul Liturghiei interioare' al eului liric aflat în căutarea lui Dumnezeu. Muzica și efectele sale terapeutice sunt tot mai studiate de specialiști, deoarece s-a observat că muzica reduce stresul, ameliorează ritmul cardiac, elimină insomniile severe, atenuează durerile fizice, le face suportabile pe cele spirituale etc. Folosirea limbajului pragmatico-muzical în definirea artei proprii este tot mai frecventă la artiștii contemporani. Adam Puslojić este unul dintre aceștia.

Cuvinte-cheie: Adam Puslojić, poésie serbe contemporaine, chant et chanson, instrument musical, ut musica poesis.

\section{Introducere}

Scriitura de bilanț este un exercițiu confesiv practicat adesea în etapa de creație artistică a deplinei maturităţi. De cele mai multe ori, ea este însoțită de un demers scrutător asupra a ceea ce a devenit, intelectual și spiritual, ființa de-a lungul vieții; este o (re)întâlnire cu oamenii, cu sufletul experimentat și trecut (victorios, probabil) prin marile confruntări. Este o privire în oglinda interioară și, mai ales, un examen autoscopic cu rol cathartic (pentru scriitor), cu bogate învătături (pentru cititorul care ia aminte).

Adam Puslojić prilejuiește cititorului său o astfel de experiență în ultimul volum de versuri Cerul, în direct, publicat în 2019. Fie că propune popasuri în timp (anii ' 80 și prietenia cu Nichita Stănescu) sau drumuri printre amintiri (confrații din Valea Timocului și din „Kraina mea natală și roditoare”, Puslojić, 2019: 64), fie că trasează o hartă spirituală a propriei deveniri întru ființă (epifaniile personale) sau încearcă să dea definiții (proprii) poeziei, poetului sau artei,

\footnotetext{
${ }^{1}$ ramona.malita@e-uvt.ro
} 
scriitorul este, pe tot parcursul acestui volum, confesiv. Ironic sau autoironic, rar; de cele mai multe ori, grav. Majoritatea poemelor (scrise între ianuarie și martie 2016) caută „ochiul lui Dumnezeu” (Puslojić, 2019: 72) prin muzica sacră. Cea liturgică. Coperta cărții reprezintă o clopotniță de mănăstire cu turnuri înalte, gri, zvelte, cu țaşnire spre cer, cu un brâu ocru sub acoperiș. În vârful celui mai înalt turn se află o cruce victorios înălțându-se spre cer. Lăcaşul de cult e aşezat pe un deal tomnatic, cu culori potolite de verde și maro. Fără îndoială, e o pădure în/de toamnă târzie, spre iarnă. Crucea și arângul sunt însemnele unei victorii personale. Cântul se asociază mereu acestei căutări, iar instrumentul muzical însoțește versul în multe poezii, așa încât creează structuri poetice în care sunetul melodios şi textul compun un tot ce, sub forme diferite, apar repetitiv şi în alte poeme. De aceea, formulăm ipoteza că poeziile acestui volum formează strofe din 'cântecul Liturghiei interioare' al eului liric aflat în căutarea lui Dumnezeu. Demersul critic este tematic, în sensul că vom lua în/spre analiză poeme și versuri din poeme pe care le vom grupa tematic pe trei invariante recurente: căutarea cu încredere, căutarea cu disperare și definițiile poetice.

În poemul Gura de miel ${ }^{2}$, motivul clopotului face legătura dintre pământ și „cerul de Isus atins” (Puslojić, 2019: 25). Motivul pământului are aici dublă semnificație: pe de o parte, pământul ca țărână din care e făcut omul și pământul ca glie, loc de baștină al omului în lume, unde își are mormântul. Preocupat de „soarta neamului omenesc din ceruri”, adică de viața de după moarte, Adam Puslojić trece cu imaginația dincolo de ,poarta lemnoasă” în dangăt de clopot care însoțește marea trecere; este aceasta o imagine indirectă - o litotă - a liturghiei? Clopotul aici este instrument (cântă) și glas (țipă) ale sufletului care urcă scara spre viața veșnică. Este pregătirea pentru moarte, este un sunet al conștiinței care se pregătește pentru lumea de dincolo în acord cu învățătura primită în copilărie despre cum moare un om, dar și un remember al educației creștine primite, probabil, de la duhovnicul copilăriei. Dacă ar fi să denumesc această imagine audio-vizuală cu un termen traductologic, aș numi-o fără ezitare culturem, pentru că are sens deplin, profund spiritual numai în context creștin, de liturghie urmărită/cântată cu sufletul. Traducerea acestei unităti de frază are ecou de zidire spirituală doar pentru un suflet familiarizat cu experiența melodico-liturgică a clopotului, ca parte a marii treceri. Dacă la romantici trecerea pragului dincolo este o formă de evadare spațială, temporală şi modalăª , la post-post-modernistul

\footnotetext{
${ }^{2}$ Volumul de versuri, Cerul, în direct, se structurează în zece subdiviziuni: Linia albastră, Ultimul punct de iute, Sub lunetă, vederea, Umbra, colorit, Linia punctuală, Idiom de răsărit, Sinapse, legături și semne, În fine, cerul personal, Singurul om din lume, Act de pietrificare. Poemul face parte din subdiviziunea Ultimul punct de iute al volumului.

${ }^{3}$ Papu, Edgar, Excurs prin literatura lumii, București, Editura Eminescu, 1990. Tipurile de evadări propuse de exegetul bucureștean sunt strâns legate de ieșirea din timpul prezent și din imediatul spațial. Evadarea temporală în trecutul personal și/sau colectiv; evadarea spațială într-o natură exotică pe care doar ochiul o vede cu ajutorul imaginației sau în alte lumi paralele: universul cosmic, alte sisteme solare sau galaxii; evadarea modală în alte tipuri de existență, printre care și
} 
Adam Puslojić pragul este trecut în şi cu tânguirea clopotului în sensul creștin al liturghiei.

În poemul Din mers, Domnul „cântă ca un solist” (Puslojić, 2019: 15) prin intermediul apei vii puse să izvorască în calea muritorilor. Oprindu-ne la cişmea să bem apă - trimitere indirectă la episodul femeii samaritence pe care Isus o întâlnise la fântâna lui $\operatorname{Iacov}^{4}$, - ne întâlnim cu cântul / cuvântul Domnului care zidește și izbăvește și, prin aceasta, aduce viața veșnică. Este poemul care explică titlul volumului, pentru că ultimul vers din strofa a treia - ,cerul, în direct” - arată cum, prin cântecul divin, poate omul să fie en ligne/online/on air cu cerul. „Aici ne-am oprit" zice Adam Puslojić și pune accentul pe legătura oprire din mers ascultarea cântului / glasului divin ca pe o condiție sine qua non a devenirii întru ființă. Nu mersul pe dinafară (exterior) e aducător de devenire întru ființă (acela e alergarea cotidiană, sortită eșecului și dezamăgirilor), ci oprirea pe dinlăuntru și apoi ascultarea cerului în direct sunt purtătoare de profunzime sprituală și de relație directă cu divinitatea. Volumul lui Adam Puslojić este o pledoarie și un manual în acest sens, pentru că este o carte de învățătură ce reunește și detaliază pași și etape pe care le putem parcurge ca să ne apropiem de Dumnezeu. Întoarcerea din tăcere, din însingurare sau din pustiire se face, ne povățuiește poetul, tot prin cântec, prin vocea lui Dumnezeu, prin ,arângul de zile mari și din altare" (Puslojić, 2019: 39) și prin glasul omului care își învinge teama (poemul Tăcere și exaltare ${ }^{5}$ ). Parigmenonul (realizat aici cu ingambament) este natural, deși mizează, structural, pe o repetiție: să-ncep să le cânt o cântare.

\section{Căutarea cu încredere}

Întreg volumul are ca leitmotiv cântul Liturghiei și al muzicii cuvântului lui Dumnezeu, îngânat în suflet. Ea este mesagerul divin pentru o închinare cu evlavie, pentru o închinare întru creștere şi zidire pe dinlăuntru. Muzica divină e catharsis la Adam Puslojić, dar, mai cu seamă, este o formă de apropiere de Creatorul, de cultivare a relației directe cu Dumnezeu. Muzica este mijlocul

moartea, sau migrația sufletului în alte vieți, palingenezia adică, de origine egipteană, sunt trei din formele de apărare ale artistului romantic de invazia societății care-l marginalizează.

${ }^{4}$ Evanghelia după Ioan, capitolul 4: 5. Isus a ajuns lângă o cetate din ținutul Samariei, numită Sihar, aproape de ogorul pe care-1 dăduse Iacov fiului său, Iosif. 6. Acolo se afla fântâna lui Iacov. Isus, ostenit de călătorie, ședea lângă fântână. Era cam pe la ceasul al șaselea. 7. A venit o femeie din Samaria să scoată apă. "Dă-Mi să beau", i-a zis Isus. 8. Căci ucenicii Lui se duseseră în cetate să cumpere de ale mâncării. 9. Femeia samariteană I-a zis: "Cum Tu, iudeu, ceri să bei de la mine, femeie samariteană?" - Iudeii, în adevăr, n-au legături cu samaritenii. -10. Drept răspuns, Isus i-a zis: "Dacă ai fi cunoscut tu darul lui Dumnezeu și Cine este Cel ce-ți zice: "Dă-Mi să beau!", tu singură ai fi cerut să bei, și El ți-ar fi dat apă vie."11. "Doamne", I-a zis femeia, "n-ai cu ce să scoți apa, și fântâna este adancă; de unde ai putea să ai, dar, această apă vie?"

${ }^{5}$ Poemul face parte din subdiviziunea Umbra, colorit. 
de căutare și de găsire a lui Dumnezeu. Experiența căutării nu e în van, căci pornește cu sentimentul încrederii că, bătând, i se va deschide, că, alergând, va primi cununa biruinței Sinelui întru devenire. Pașii îi sunt siguri, pentru că a ales drumul cel bun.

Muzica liturghiei deschide cerurile în poezia lui Adam Puslojić, pentru că duce mai aproape sufletul omului de închinarea la Dumnezeu și, prin aceasta, de mântuire. Muzica liturgică dă sens, de fapt, acestui cotidian apăsător; duce deci spre libertate, pentru că doar adevărul ne face slobozi ${ }^{6}$ : ,noi intrăm liberi în el [în cer] ", spune apăsat Adam Puslojić (2019: 43) în poezia Astăzi cântăm liturghia, din subdiviziunea Umbra, colorit. Aflat în ultima etapă de creație, volumul este o scriitură de bilanț, o scrutare a trecutului pentru a-l privi detașat, sine ira et studio și, poate, pentru a se elibera de copleșeala prezentului împovărător, însă cu gândul la aventura celestă la care azi e chemat de „fanfara de o sută şi nouă trompete” (Puslojić, 2019: 43). Sunt trompetele îngerilor din Apocalipsa care cântă cântecul victoriei? $\mathrm{Nu}$ știm, scriitorul nu spune desluşit, însă ideea repetitivităţii din ultimul vers: „şi mâine mai vine una!" - marcat grafic cu italice față de cele șase terține ale poeziei -, arată că experiența disforică a clipei prezente va fi anulată de cea euforică a urcării la cer și a trecerii pragului dincolo. Sfârșitul vieții nu-i generează frică, ci, în sunet de muzică și cu fanfară, i se pare că e o nuntă, cu lumini și melodii cerești. A asculta Sfânta Liturghie este o jubilație de acest fel: eul liric, aflat în ipostaza de meditativ, construiește aici o metaforă binară in absentia: ,,aventură celestă” și ,nuntă la țară” pentru a desemna viața veșnică.

În poemul Copacul (p. 63) din subdiviziunea Idiom de răsărit, apare motivul copacului cântător prin privighetorile care și-au făcut cuib între ramurile lui. În crengile cu fructe stau privighetorile să-i cânte lui şi omului cu gândul deschis despre Dumnezeu, cu note din cartea Liturghiei, în amintirea întâiului cântec din Rai. Poate e copacul cunoașterii Binelui și al Răului, pomul lui Dumnezeu, cu muzică divină în el: este axa cerului și reprezintă legătura între cer și pământ ${ }^{7}$. Că e din grădina Raiului e de-nțeles cu deasupra de măsură, e mereu în prezența lui Dumnezeu, căci a devenit carte și apoi Cuvânt, Logos, Cel ce era una cu Domnul la facerea lumii ${ }^{8}$. Este copacul ce, într-un alt poem, ,ne-aduce nevăzut la

\footnotetext{
${ }^{6}$ Ioan 8:32 Veți cunoaște adevărul, și adevărul vă va face slobozi.

${ }^{7}$ Arborele cosmic, pomul vieții sau coloana cerului exprimă evoluția omului în concordanță cu mediul înconjurător. La început oamenii considerau anumiți arbori sacri, asociați cu importantele evenimente ale existenței: nașterea, nunta, moartea. Pomul vieții este și arborele justițiar, arborele fertilizator. Primele reprezentări ale arborelui cosmic sunt arborele de pe plăcuța dreptunghiulară de la Tărtăria, coloana cerului de la Căscioarele, coloana dacă de pe Columna lui Traian. Cea mai rafinată reprezentare este Coloana infinitului a lui Brâncuși de la Târgu Jiu. Pentru o prezentare detaliată a reperelor astronomiei culturale, vezi Frîncu, Marc și Frîncu, Simina et alii, Universul astronomiei, Societatea română pentru astronomie culturală, 2018.
}

${ }^{8}$ EVANGHELIA DUPĂ IOAN : Întruparea Cuvântului. 1.La început era Cuvântul, şi Cuvântul era cu Dumnezeu, şi† Cuvântul era Dumnezeu††. 2. El era la început cu Dumnezeu. 3. Toate lucrurile au fost făcute prin El; şi nimic din ce a fost făcut n-a fost făcut fără El. 4. În El era viaţa, şi viaţa era 
arângul îngerilor" (Puslojić, 2019: 64), căci este lemnul din care vor face scara urcării noastre spre cer (precum în Gorunul lui Blaga, era copacul din care vor face cândva, la apusul vieții, sicriul). Motivul privighetorii este reluat în poemul Iisus ne-a spus, doar că aici e termenul unei comparații vizibile și al unei litote de substrat, pentru că aparenta micime a omului ,în universul închis” (Puslojić, 2019: 73) e negată de muzica privighetorii, muzica divină din noi, cei locuiți de Dumnezeu. Aici pasărea cântătoare trimite spre Duhul Sfânt pe care Domnul 1-a trimis ca ambasador să ne locuiască și, prin aceasta, să căpătăm înțelepciunea.

\section{Căutarea cu disperare}

O notă de disperare regăsim în poezia Ai cui suntem? (2019: 77), din subdiviziunea În fine, cerul personal (intrarea-n martie) și tot în legătură cu muzica. De data aceasta funebră, pentru că „A murit cutare anonim de neuitat este astăzi opera lui muzicală” (Puslojić, 2019: 77). O construcție privilegiată, cu oximoron, chiar dacă nu versurile acestea sunt cheia poeziei, ci „Dumnezeu găsit pe drumuri mereu". De El, prin El și pentru El sunt toate lucrurile, căci El este cheia identităţii noastre, de aceea vine în finalul poemului întrebarea-clauzulă: „Al cui este?” în oglindă cu titlul: Ai cui suntem? Răspunsul este dat în versurile antepenultim și penultim, deja citate. Găsesc că Adam Puslojić dă la iveală în acest volum, pas cu pas, teologia pe înțelesul personal; tocmai de aceea subdiviziunea se numește În fine, cerul personal. Asocierea aceasta între substantiv și adjectiv e cu totul neașteptată, dar justă, pentru că grăiește din adâncul sufletului, pătruns de esența divină pe care o verbalizează, o interiorizează și o aplică personal; arată, altfel spus, cum a înțeles eul liric complicata teologie biblică: este versiunea subiectivă a experienței cerului în direct sau a epifaniei. La Adam Puslojić (2019: 77) această întâlnire cu sacrul e însoțită neapărat de muzică, „de orga cerului” și „,de pianul pământului” (alt joc antitetic construit pe aceeași linie cu oximoronul din versurile de la începutul poemului). Întrebându-se al cui este cel mort, se îngrijorează, de fapt, de sine şi de speța umană, devreme ce generalizează interogația prin folosirea persoanei I plural. Moartea e creionată muzical prin ruperea ritmului (vieții, desigur!), pe lângă că e,,un sunet azvârlit și dat peste cap”. Dacă „Domnul e pe drumuri mereu” (ca în povestea lui Ivan Turbinca a lui Ion Creangă), eul liric e (uşor sau mai mult) neliniștit, ca și cum plecarea în călătoria pământeană a Divinului (întruparea Domnului adică) are drept consecință un cer gol, lipsit de dumnezeire, în așteptarea reîntoarcerii Creatorului. E o umbră de îndoială aici, izvorâtă din teama de a fi lăsați de izbeliște, pentru că se obișnuise cu starea „de vorbă cosmică ” și cu cina laolaltă cu El.

În poemul Un război, o umbră, toba anunță războiul și, implicit, haosul, deși e sunet ritmic; anunță moartea, deși e ceas cu cuc (Puslojić, 2019: 49). Stabilitatea casei și confortul interiorului burghez mobilat cu un ceas de perete cu cuc sunt

lumina oamenilor. (Ioan, 1 - Resurse Creștine (resursecrestine.ro)) 
anulate de sunetul sacadat, tunător, al tobei cu veste de război. Muzica aici nu mai are efectul eufonic al terapiei, ci e disforic, vestind conflagrație; muzica nu mai este armonie și nici ritm, efectul melodiei a fost anulat de simbolistica morții, a devenit zgomot, strigăt de deznădejde în spatele căruia simți frică, adică frici de felurite soiuri. Paralizante toate. Și împovărătoare: ce departe e sunetul mângâietor și alinător ale liturghiei!

În poemul Acolo, in cer din subdiviziunea În fine, cerul personal (intrarea-n martie), Adam Puslojić creionează o patrie terestră al cărei corespondent (tot muzical) este o patrie cerească: jos, existența a devenit „un vaiet muzical și sonor”; sus, este „un țipăt direct din creier” (Puslojić, 2019: 82), deci strident și nearmonios. Este, probabil, o proiecție muzicală a incertitudinii legate de viața de dincolo, dorite totuși. Aceeași temă a nesiguranței răzbate și din poezia Un viu (2019: 88), pentru că eul liric, îngrijorat de viață și de moarte, compară ,lumea normală”, care „cântă și dansează” (Puslojić, 2019: 88), cu moartea. Deocamdată a altora, întrucât el este un viu. Așază aici din nou în raport patria de jos cu patria de sus: pe prima o știe, o verbalizează, o descrie, o judecă, o evaluează (şi e nemulțumit); pe a doua o presupune, o bănuie (din cele ce știe despre ea) și, mai ales, o dorește, deși nu-i este familiară. Busola spre patria cerească este inima, „,ăci pentru creier este prea târziu!” (Puslojić, 2019: 88).

\section{Definiții poetice}

Adam Puslojić încearcă adesea definiții personale ale adevărurilor esențiale din existența lui: viața, omul, poetul, Dumnezeu, poezia, cerul etc. De pildă, în Singurul om din lume (2019: 79), motivul vieții este folosit cu sensul de bios, durată personalizată de un număr de ani, în opoziție cu $Z \omega \dot{\eta}(Z o e ́)^{9}$-viața ca existență, opusă morții; în încercările de definire, poetul se folosește de culoare și de sunet, de simbolistica cromatică și de echivalentul ei sonor, dacă ar fi să apelăm la cromismul sonor sau la audițiile colorate: „,viața este albastră și ea cântă”. E un albastru muzical cu totul posibil, după cum atestă multiplele mărturii ale celor ce aud culori. Asocierea/corespondența culoare-sunet nu e sumbră în poezia lui Adam Puslojić, nici disforică, dimpotrivă, e generatoare de experiențe mistice

\footnotetext{
${ }^{9}$ Zóe reproduce pe cale cultă gr. Zoé, cu semnificație clară pentru greci, care foloseau același cuvint pentru „viață”. De origine indo-europeană, gr. zoe aparține aceleiași familii în care intră gr. bios. După cum atestă izvoarele, se pare că numai în epoca creștină, o primă apariție a acestuia este semnalată chiar în versiunea grecească a Vechiului Testament, Septuaginta, unde Zoe este folosit într-un pasaj al Genezei în locul lui Eva, fiind vorba, deci, de o traducere a numelui ebraic. Preluat chiar și de către evreii care trăiau în ambianța elenistică, Zoe se răspândește rapid în mediile creștine de limbă greacă datorită conceptului mistic al „,vieții de apoi”, singura şi adevărata viață spirituală a credinciosului (de ex., cultul martirilor și sfinților a fost fixat de biserică în ziua morții lor, considerată adevărată naștere). Ionescu, Christian, Mică Enciclopedie Onomastică, București, Editura Enciclopedică Română, 1975. Surse / dexonline.
} 
și de epifanii. În Poeții dă o definiție indirectă poeziei: compusă din „cântec, silabă și literă”(Puslojić, 2019: 88), ea răsună ca ,un clopot de zile mari” (2019: 88). Legată deci de cântecul liturgic, poezia, în viziunea lui Adam Puslojić, este imperios necesară devenirii spirituale și culturale a unui neam; „secolul luminos” (clauzula poemului Poeții la care facem referire aici) este devenirea unei nații întru poezie și e dat de cântarea poetică. Remarcăm o analogie cu muzica liturgică pentru a obține perfecțiunea formei poetice.

Poetul este dator să continue cântarea, pentru ca neamul lui să-și continue istoria culturală. În subdiviziunea Idiom de răsărit, găsim o definiție a omului din perspectiva lui Adam Puslojić: „El devine un sunet împietrit” (2019: 58), dacă nu comunică în direct cu cerul. Folosindu-se de oximoron, Adam Puslojić definește ființa umană - în poemul Omul - în termeni de sunet și melodie, deveniți leitmotivele acestui volum.

O nuanță nouă e adăugată definiției poeziei în De-a mea zi de renaștere: poezia dă aripi vieții de poet, iar „el levitează” (2019: 81). Că merge ori că zboară, poetul cântă în și prin poezia lui: ,un cuvânt luminos din gură ieșit spre cer ori infern” (2019: 81). Observăm o dată în plus preferința pentru structurile poetice antitetice așezate în disjuncție, spre alegerea dilematică. Întrebarea retorică e presupusă, deoarece nu este marcată prin semnul întrebării, ci doar prin adverbul interogativ cum, însoțit de adverbul deictic atunci. Adam Puslojić se folosește de sinecdocă în încercarea de a defini poezia, întrucât numește partea pentru întreg: ,, continuăm cântarea/ și fiecare silabă și literă răsună ca un clopot" (2019: 81), unde substantivele silabă și literă desemnează întregul vers. În același poem despre rostul poeziei folosește o altă sinecdocă, pentru că atribuie secvenței „un cuvânt luminos din gură ieșit” un înțeles mai larg decât cel pe care îl are în realitate. Aici este evidentă folosirea sintagmei pentru a desemna poezia și, în acest sens, sinecdoca se află la graniță cu litota, pentru că spune mai mult prin mai puțin. Corelată cu litota este catacreza de care poetul se folosește în multiple rânduri: cântecul este poezia muzicală, așa cum muzica Liturghiei este mesagerul Domnului. Ieșirea din ,spațiul blestemat” (2019: 81) al cotidianului-închisoare se face prin poezia cântată ${ }^{10}$, căci sunetul melodios ridică din imediatul clipei, prelungind timpul și dilatând clipa umană.

În ultimul poem al volumului (semnat 31 martie 2016, aflat deci la 'ieșirea din martie', dacă ar fi să ne raportăm la subtitlul subdiviziunii: intrarea-n martie), Adam Puslojić (2019: 89) încearcă din nou o definiție muzicală a poeziei: „Un cântec străvechi cu praf de aur". Cele cinci vocale sonore ale limbii, aflate în traista imaginației și a gândirii poetice, nu trebuie date de tot, ci reînnoite, nu trebuie epuizate, ci înmiite: ,altfel cu ce mai cântăm?” (Adam Puslojić, 2019: 89) Aș numi aceste definiții muzicale arte poetice, pentru că, indirect, dezvăluie cititorului aspecte ale gândirii poetice creatoare. De fiecare dată leagă poezia de muzica celestă, ritmul (toba!) versului cu cel al muzicii în general, al liturghiei, în particular.

$\overline{{ }^{10} \text { Catacreza este figura retorică de bază a acestui poem. }}$ 


\section{Concluzie}

Sensibil, cântând în surdină Liturghia personală a întâlnirii cu Domnul, volumul întreg este o frământare autoscopică a scriitorului pentru a nu rata epifania. Această experiență cu divinul îi este esențială pentru continuarea vieții dincolo, căci moartea este, în poezia lui Adam Puslojić, un prag pe care îl trece pentru a trăi viața veșnică spre care tânjește, adică pentru a obține împăcarea cu Dumnezeu. Nu dorește să lase să treacă pe lângă el sărbătoarea personală a împreunării spirituale cu cerul. De aceea, aidoma unui jurnalist de radio sau de televiziune, își intitulează volumul Cerul, in direct.

Tonul este de confesiune poetică, pentru că verbalizează felul în care înțelege, mereu proaspăt, adevărurile esențiale ale existenței. Muzica merge mână în mână cu confesiunea lirică, o face mai autentică și mai pătrunsă de emoție. Cântul potențează poezia, o încarcă cu puteri nebănuite de pătrundere în suflet. Sunetul clopotului face mai suportabilă purtarea cotidiană a crucii. Condițiile sunt două: ascultarea cu atenție a acestei muzici și distingerea ei în tumultul zgomotului cotidian.

Cunoașterea lui Dumnezeu este transformatoare pentru orice suflet, pentru că modifică „destinația finală” a lui; prosternarea prin cântecul liturgic în fața cerului este, de fapt, o reconfigurare a traseului pentru restabilirea destinației: viața de Apoi. Calea pe care Adam Puslojić o vede viabilă pentru acest lucru este muzica, melodia cerească, cântul liturgic, instrumentul muzical, poezia-cânt. Dătătoare de speranță, muzica îl însoțește pe acest drum al căutării de sine atât în momentele de certitudine, cât și în cele de nesiguranță, atât în valea umbrei morții, cât și pe vârf de munte.

\section{Bibliografie}

\section{Text de referință}

Puslojić, 2019: A. Puslojić, Cerul, in direct. București: Tracus Arte.

\section{Bibliografie critică}

Biblia. Versiunea Dumitru Cornilescu, online. https://biblia.resursecrestine.ro/ (consultată în 29 decembrie 2020)

Frîncu, 2018: M. Frîncu; S. Frîncu et alii, Universul astronomiei. Timişoara: Societatea română pentru astronomie culturală.

Ionescu, 1975: C. Ionescu, Mică Enciclopedie Onomastică. București: Editura Enciclopedică Română.

Magheru, 1972: P. Magheru, Probleme de teorie și analiză literară. Oradea: Editura Universității din Oradea.

Papu, 1990: E. Papu, Excurs prin literatura lumii. București: Editura Eminescu. 


\title{
HISTOIRE D'UN GLAS. LE MOTIF DU CHANT DE LA MESSE CHEZ ADAM PUSLOJIC
}

\begin{abstract}
Résumé
Notre étude se donne pour but d'investiguer le motif de la chanson dans la poésie d'Adam Puslojić. Point de départ : utilisant l'expression d'un langage pragmaticomusical, la musique réduit le stress, améliore le rythme cardiaque et les insomnies, atténue les douleurs physiques, etc. ; la musique, apprécient les spécialistes, est de plus en plus étudiée pour surprendre ses effets thérapeutiques. Corpus : l'un des derniers volumes de poésie - Cerul, în direct-, publiés par l'écrivain serbe contemporain mentionné ; les motifs du chant, du son musical, de l'instrument musical se combinent ici avec une thématique religieuse ; ensemble, chant et religion, forment des 'synapses', des 'liaisons' et des 'signes' (termes inclus dans un sous-chapitre de ce recueil) dont nous proposons une interprétation en clé herméneutique. Hypothèse de travail : les poésies de ce volume sont des 'strophes' d'une 'Messe' intérieure, à la recherche d'un Dieu « cheminant toujours ».

Mots-clés : Adam Puslojić, poésie serbe contemporaine, chant et chanson, instrument musical, ut musica poesis.
\end{abstract}

